\title{
Perubahan Kebiasaan Makan di Restoran Dalam Masa Pandemi COVID-19: Keamanan dan Pelayanan Pangan
}

\author{
Yelia Santoso ${ }^{\mathrm{a}, 1 *}$ \\ a* Program Studi Pariwisata, Fakultas Pariwisata, Universitas Ciputra Surabaya, Citraland CBD Boulevard, Made, \\ Sambikerep, Surabaya, 67219, Indonesia \\ 1ysantoso02@student.ciputra.ac.id* \\ *penulis korespondensi
}

\begin{abstract}
The purpose of this study was to examine the effects of food safety and food service on eating habits in restaurants. Food service was also tested as a mediating variable in this study. Since the pandemic, the implementation of food safety and food services has undergone a complete change. Government regulatory health protocols should be implemented to reduce foodborne transmission. This study was conducted quantitatively by using PLS-SEM analysis. Data was collected once (cross sectional) by distributing questionnaires purposively to individuals who were still eating in restaurants during the pandemic. The number of samples in this study were 64 respondents. This study concludes that food safety is very important for consumers so that when they are dine-in they feel safe. Meanwhile, food service has no significant effect either as an independent variable or as a mediator in the relationship between food safety and eating habits. Suggestion for the stakeholders is to provide a number of tools that can be used by consumers independently to reensure that they feel safe when dine-in at a restaurant. Included in this category are disinfectants for hands, also for tables, and cutlery. Even so, the food service implementation protocol must also be implemented.
\end{abstract}

Keywords: dine-in, eating habits, food safety, food service

\begin{abstract}
ABSTRAK
Tujuan penelitian ini adalah untuk menguji efek food safety dan food service terhadap eating habits di rumah makan. Food service juga diuji sebagai variabel mediasi di dalam penelitian ini. Sejak masa pandemi, perubahan pelaksanaan keamanan pangan dan pelayanan pangan mengalamai perubahan total. Peraturan protokol kesehatan dari pemerintah harus diterapkan untuk mengurangi penularan melalui makanan. Studi ini dilakukan secara kuantitatif dengan menggunakan analisis PLS-SEM. Data diambil satu kali (cross sectional) dengan membagikan kuesioner secara purposif kepada individu yang masih makan di rumah makan pada masa pandemi. Jumlah sampel dalam penelitian ini adalah 64 responden. Studi ini menyimpulkan bahwa food safety sangat penting bagi konsumen agar ketika dine-in mereka merasa aman. Sementara itu food service tidak berpengaruh signifikan baik sebagai variabel independen maupun mediasi dalam hubungan pengaruh antara food safety dan eating habits. Saran bagi pemangku kepentingan adalah dengan menyediakan sejumlah sarana yang dapat digunakan oleh konsumen secara mandiri untuk memastikan kembali bahwa mereka merasa aman ketika dine-in di restoran. Termasuk dalam kategori ini adalah disinfekan untuk tangan, juga untuk meja, dan sendok garpu. Sekalipun demikian protokol pelaksanaan food service juga tetap harus dilaksanakan.
\end{abstract}

Kata Kunci: jasa makanan, keamanan pangan, kebiasaan makan 


\section{Pendahuluan}

Umum diketahui, Covid-19 mulai menyebar pada awal bulan Januari 2020 di Indonesia. Sebagian orang lebih suka untuk memilih membeli makan di luar rumah dibandingkan makan yang dibuat sendiri di rumah karena beberapa hal, di antaranya, ingin mendapat suasana baru, mencicipi makanan dengan rasa berbeda, dan meluangkan waktu dengan makan di luar rumah. Hal ini menjadi kebiasaan pada orang yang sering melakukannya, dinamakan dengan eating habits. Banyak orang memiliki eating habits untuk dine-in di restoran dengan berbagai macam alasan. Mulai dari bosan dengan masakan buatan rumah, tidak mempunyai waktu luang untuk mempersiapkan makanan, malas mencuci piring, dan kebetulan pergi bersama dengan kerabat sehingga mau tidak mau akan makan di luar rumah (Di Renzo et al. 2020). Tidak heran banyak restoran yang membuka meja untuk melayani para pelanggan yang hobi untuk dine-in atau hanya sekadar kebetulan makan di luar. Eating habits juga berbicara tentang sikap para pelanggan menanggapai makanan yang telah disajikan (Lee 2019). Perilaku para pelanggan dalam makanan yang disajikan berbeda-beda mulai dari menikmati makanan karena mereka suka dengan menu yang ada di restoran dan peduli dengan lingkungan sehingga tidak akan membuang makanan dengan sia-sia. Ada juga yang tidak memperhatikan hal-hal lain sehingga ketika mereka sudah kenyang, maka akan meninggalkan makanan itu tanpa membungkusnya. Secara tidak langsung, para pelanggan yang dine-in di restoran juga akan memperhatikan dan menjaga keamanan pangan sebelum mereka mengkonsumsinya.

Virus corona dapat bertahan dan berkembang melalui hewan atau manusia tetapi tidak melalui makanan dan kemasan makanan. Banyak orang yang berasumsi bahwa virus ini bisa berada di mana saja, terutama di makanan. Virus corona merupakan virus yang serupa dengan SARS dengan ukuran partikel sangat kecil membuat orang-orang menjadi paranoid akan kebersihan terutama pada food-safety. Perilaku paranoid atau ketakutan berlebihan di lingkungannya muncul karena adanya disorganisasi dalam masyarakat akibat virus Covid19. Menurut WHO, makanan tidak akan menyebabkan virus corona menyebar, termasuk fresh food seperti buah-buahan dan sayur-sayuran. Penelitian terdahulu juga menjelaskan bahwa makanan bukan jalur penyebaran dan penularan virus corona (Han et al. 2020). Faktor lain yang menyebabkan munculnya pemikiran paranoid ini dikarenakan kurangnya pengetahuan tentang penyebaran virus corona, munculnya berita hoax di media sosial, kurangnya himbauan pemerintah tentang keamanan makanan di masa pandemi, dan kurang ketatnya pemberlakuan peraturan seperti PSBB, penggunaan akrilik sebagai pembatas di meja, tanda dilarang duduk yang dilanggar, dan menggabung meja untuk makan bersamasama.

Adapun orang-orang yang ingin keluar untuk mencari makan di restoran melakukan beberapa hal untuk mengurangi rasa paranoid seperti menjaga diri dengan mencuci tangan selama minimal 20 detik, membilas peralatan makan, membersihkan tempat wadah makan untuk memastikan tetap tersanitasi dengan baik, pengukuran suhu tubuh dengan menggunakan thermometer guns tidak lebih dari $38^{\circ} \mathrm{C}$ (Shahbaz et al. 2020). Perilaku lain yang dilakukan oleh orang-orang adalah membeli makanan secara delivery melalui restoran atau online service seperti Grab Food dan Go-Food. Orang-orang yang membeli makanan secara delivery akan mendapat packaging dengan menggunakan zip-tie, 
memastikan makanan tetap tertutup rapat sampai kepada pelanggan. Setelah makanan datang, mereka akan melakukan sterilisasi pada packaging makanan dan memanaskan makanan dengan microwave atau oven, bahkan menggoreng atau mengkukus kembali makanan tersebut. Keamanan dalam pelayanan makanan menjadi hal yang diperhatikan oleh pelanggan dan secara tidak langsung dapat mengubah kebiasaan makan selama pandemi berlangsung (Chow 2020). Perubahan kebiasaan makan pelanggan yang terlihat jelas selama pandemi adalah dine-in. Pelanggan lebih memilih untuk melakukan delivery dibandingkan dine-in di tempat makan.

Di sisi lain pemilik restoran akan tetap bertahan selama masa pandemi berlangsung dengan memberikan pelayanan yang tidak membuat orang-orang takut untuk membeli. Pemilik restoran akan melakukan pengecekan suhu tubuh para pelayan yang ditulis di papan, menyediakan air panas untuk membersihkan peralatan makan, menyediakan hand sanitizer, dan memastikan pelayanan yang diberikan mematuhi protokol kesehatan. Keamanan pangan merupakan salah satu hal penting yang perlu diterapkan pada pelayanan makanan, mulai dari pengambilan order makanan, penerimaan makanan, persiapan menyajikan dan pengemasan makanan, hingga pengiriman makanan kepada pelanggan (Shahbaz et al. 2020). Sebelum menyentuh makanan, sebaiknya para pelayan mencuci tangan selama minimal 20 detik, melakukan sanitasi diri, menggunakan masker, dan melindungi dengan alat pelindung diri (APD). Selain pelayanan secara langsung, adapun alternatif layanan lain yang dapat diberikan kepada pelanggan saat membeli makanan secara delivery. Layanan dengan memberikan pentunjuk memasak atau memanaskan makanan. Cara seperti ini dapat mempermudah pelanggan dalam mengkonsumsi. Selain memberikan rasa percaya kepada pelanggan, mereka akan merasa aman ketika hendak mengkonsumsi makanan tersebut. Dengan adanya memberikan instruksi sederhana dalam memanaskan makanan tersebut membuat pelanggan merasa puas dan diperhatikan secara tidak langsung. Oleh karena itu tujuan penelitian ini dibuat untuk meneliti perubahan orang dalam eating behaviour selama masa pandemi dan menyediakan edukasi kepada pemilik restoran betapa pentingnya pengaruh keamanan makanan dan kualitas pelayanan makanan.

Keamanan dalam makanan merupakan hal yang wajib terpenuhi untuk menjaga tingkat higenitas makanan. Suatu produk yang diolah harus melewati sanitasi dan higenitas agar mencegah kejadian tubuh keracunan makanan. Tidak hanya tentang keamanan produk atau bahan yang diolah, tetapi juga kebersihan perlu dijaga (Han et al. 2020). Sejak munculnya virus corona di dunia, banyak orang merasa keamanan dalam pangan merupakan hal utama yang perlu diterapkan sebelum mengkonsumsi. Pemerintah juga mengingatkan tentang $3 \mathrm{M}$ yaitu mencuci tangan, menjaga jarak, dan memakai masker. Selain itu menjaga keamanan dari pihak restoran dengan penerapan precautionary measures (Shahbaz et al. 2020) seperti menjaga higenitas dengan mencuci tangan minimal 20 detik bagi para pelayan sebelum dan sesudah menyajikan, memakai masker dan alat perlindungan diri (APD) bila diperlukan, menjaga jarak antar orang saat di restoran dengan menerapkan tanda silang (X) pada meja dan membatasi dengan menggunakan akrilik, dan melakukan pengecekan suhu pada tubuh pelanggan yang datang dan seluruh pelayan (Shahbaz et al. 2020).

Keamanan pangan juga berbicara tentang bagaimana menjaga kebersihan pada food surface seperti meja, kursi, food handlers atau gagang pintu, working stations, peralatan 
masak dan makan lainnya. Semua hal tersebut dapat mempengaruhi makanan secara tidak langsung saat sedang menyiapkan food operations dan food produces. Penelitian sebelumnya menyatakan bahwa belum ada studi yang menjelaskan bahwa makanan atau food produces merupakan penyebaran virus (Olaimat et al. 2020). Mengenal food safety bukan hanya tentang keamanan pangan saja tetapi berbicara tentang area sekitar. Penelitian sebelumnya juga menjelaskan pentingnya menjaga keamanan pangan (de Andrade et al. 2020). Keamanan pangan berbicara tentang keadaan di lingkungan dan area sekitar saat proses pengolahan makanan yang memadai. Semakin tinggi kebersihan di sekitar lingkungan, maka keamanan pangan akan terjamin higenitasnya. Dengan demikian dapat meningkatkan appetite dalam mengonsumsi makanan tersebut. Sehingga penulis dapat menduga bahwa kajian teori untuk hipotesis penelitian ini adalah :

H1. Food safety berpengaruh signifikan terhadap food service.

$\mathrm{H} 2$. Food service berpengaruh signifikan terhadap eating habits.

\section{Food Service}

Pelayanan makanan merupakan suatu layanan yang diberikan kepada pelanggan saat makan di restoran. Suatu layanan yang diberikan secara profesional dapat meningkatkan appetite pelanggan dalam mengkonsumsi makanan secara tidak langsung (Chow 2020; Lee 2019). Layanan secara profesional yang dapat diberikan kepada pelanggan seperti menyambut hangat tamu dengan senyuman dan sapaan, fasilitas yang disediakan berupa memberi napkin, hand sanitizer, dan menawarkan produk baru launching kepada pelanggan (Edwards 2013). Pelayanan makanan tidak hanya berbicara tentang menyambut pelanggan saat datang, tetapi juga kebersihan dalam restoran. Perlu diketahui bahwa menjaga kebersihan dapat meningkatkan kualitas layanan (Lee 2019). Dengan demikian pelanggan akan merasa diperhatikan dan merasa aman saat datang untuk dine-in atau order via delivery. Selama masa pandemi, meningkatkan dan menjaga kualitas layanan juga hal yang penting dengan menerapkannya sesuai protokol kesehatan (Shahbaz et al. 2020). Adapun beberapa protokol kesehatan yang dapat diterapkan seperti wajib menggunakan masker, mengukur suhu tubuh menggunakan thermometer gun, menggunakan hand sanitizer sebelum menyentuh barang, mencuci tangan selama minimal 20 detik sebelum dan sesudah melayani, dan membersihan peralatan makan untuk memastikan makanan tersanitasi dengan baik.

Pelayanan makanan di luar restoran juga menjadi poin penting dan menjadi penilaian oleh pelanggan. Berita yang ditulis oleh CNN Indonesia juga menyatakan bahwa menerapkan protokol kesehatan saat melakukan delivery kepada pelanggan dengan memastikan makanan tertutup rapat dan memakai zip-tie pada plastic bag. Hal tersebut dilakukan untuk menghindari makanan terkontaminasi dari bakteri dan virus, meskipun penelitian sebelumnya menyatakan bahwa makanan bukanlah menjadi jalan penyebaran virus. Hal lain yang dapat meningkatkan kualitas layanan adalah sistem pembayaran. Menurut Kompas.com, ada baiknya untuk menggunakan pembayaran menggunakan uang elektronik dan dihimbau untuk meminimalisir pembayaran menggunakan uang tunai. Maka dari itu pemberian layanan dengan sistem pembayaran dapat dilakukan dengan cara elektronik seperti menggunakan barcode saat hendak membayar untuk meminimalisir 
penyebaran virus dan membuat pelanggan tetap merasa aman. Berdasarkan kajian teori yang telah dilampirkan, maka penulis menyimpulkan hipotesis dalam penelitian ini yaitu :

\section{Eating Habits}

Kebanyakan orang senang untuk makan di luar rumah karena beberapa ada yang beropini jenuh saat makan di rumah atau ingin mencoba masakan dengan rasa yang berbeda. Hal itu membuat banyak orang memilih untuk makan di restoran bersama keluarga atau kerabat sambil berkumpul bersama. Tidak lama masa pandemi pun tiba, semula yang awalnya makan di restoran sekarang dilarang untuk dine-in dan dianjurkan untuk makan di rumah masing-masing. Hal tersebut merubah $180^{\circ}$ kebiasaan orang makan dikarenakan ada yang takut untuk makan di luar karena takut terinfeksi virus, ada ingin menjaga keamanan dan kesehatan keluarganya, atau beberapa orang mematuhi aturan pemerintah untuk tidak dine-in (Shahbaz et al. 2020). Dalam keadaan tersebut membuat pemilik restoran mengharuskan merubah sistem dan layanan sesuai dengan protokol kesehatan sehingga orang-orang ingin kembali makan di tempat. Meyakinkan pelanggan untuk dine-in selama masa pandemi bukan hal yang mudah. Tidak hanya harus membuat pelanggan merasa aman, tetapi juga nyaman menyesuaikan dengan keadaan dan kondisi di masa pandemi.

Dalam kajian teori yang telah dikemukakan, penulis menyimpulkan hipotesis penelitian ini adalah H3: Food safety berpengaruh signifkan terhadap eating habits (Gambar 1.1).

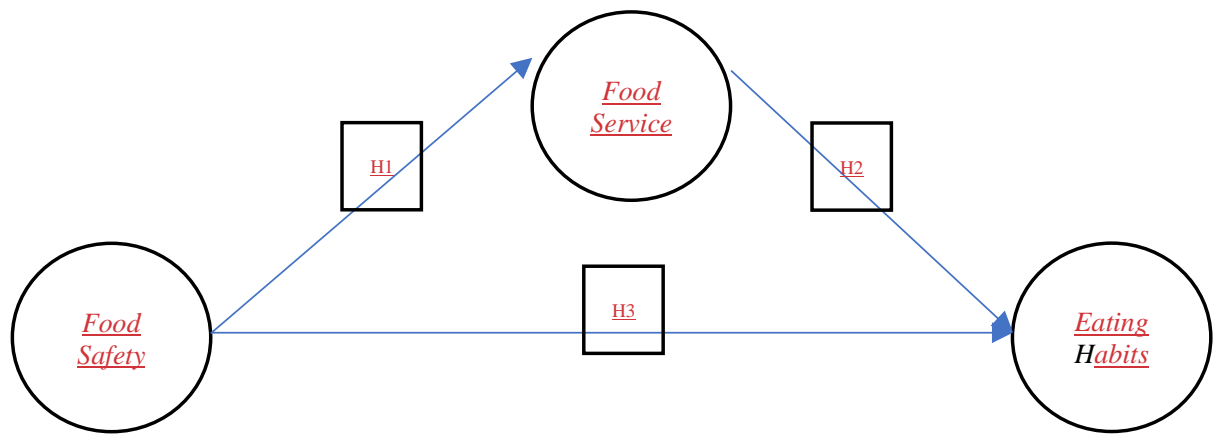

Gambar 1.1. Model Penelitian

\section{Metode Penelitian}

Penelitian ini menggunakan metode penelitian kuantitatif dengan menggunakan PLSSEM (Hair Jr. et al., 2014). Alat analisis yang digunakan adalah SmartPLS versi 3.2.8. Penelitian ini memiliki jumlah responden sebanyak 64, maka dari itu sample dengan jumlah kecil baik untuk diuji dengan PLS-SEM. Metode yang digunakan merupakan kuantitatif multivariat. Analisis multivariat digunakan untuk mengolah dan mencari pengaruh antar variabel-variabel terhadap suatu obyek secara stimultan. Sampel diambil dari individu-individu yang pernah makan di luar rumah setidaknya satu kali dalam sebulan selama pandemi. Usia dari pengambilan sampel mulai dari 17 tahun ke atas. Pengambilan sampel melalui Google Form yang disebarkan secara online. Pengambilan sample dilakukan pada warga Surabaya bagian timur sebanyak satu kali (cross-sectional) dengan pengambilan periode data selama 3 sampai 5 hari. Penelitian ini dilakukan untuk meneliti hubungan food safety dan food service yang dapat mempengaruhi kebiasaan 
makan para pelanggan. Penyebaran kuisioner dilakukan secara purposif kepada konsumen yang telah ditargetkan untuk dianalisa perubahan eating habits yang dipengaruhi oleh food safety dan food service.

Pengujian dengan menggunakan teknik analisis PLS-SEM dilakukukan dengan pengujian pada outer dan inner model. Pengujian pada outer model dilakukan secara reflektif untuk menguji reliabilitas dan validitas measurements. Adapun parameter reliabilitas adalah Chronbach's Alpha harus lebih besar daripada 0,7 dan composite reliability harus lebih besar daripada 0,5. (Gozali dan Latan, 2015) Uji validitas dilakukan dengan parameter outer loadings harus lebih besar daripada 0,6. Hal ini merujuk pada pendapat Chin (1998) yang menetapkan bahwa parameter 0,6 dapat diambil untuk measurements yang baru dibuat sehingga sifatnya masih exploratory karena kasus pandemic yang masih baru. Kemudian, parameter lain yang diuji adalah convergent validity $(A V E)$ dengan nilai lebih besar daripada 0,5, dan composite reliability lebih besar daripada 0,7. Setelah dilakukan uji outer model, selanjutnya dilakukan uji pada inner model. Untuk itu dilakukan bootstrapping dengan setup yang tidak diubah, yaitu sub samples 500 dengan sig 0,05 (Gozali dan Latan, 2015; Hair Jr. et al., 2014).

\section{Variabel, Indikator, dan Tolak Ukur}

Indikator variabel food safety diambil dari Shahbaz et al. (2020). Indikator untuk variabel food service diambil dari Chow (2020) dan Shahbaz et al. (2020). Indikator variabel eating habits diambil dari Lee (2019). Jumlah measurements dalam kuesioner adalah 31 pernyataan yang diberikan kepada responden. Pernyataan tersebut dibuat dan disesuaikan dengan indikator sebelumnya. Kuisioner ditulis dalam Bahasa Indonesia. Pernyataan dari indikator penelitian diukur dengan menggunakan skala Likert, dengan skala 1 sampai 6, atau dari "sangat tidak setuju" hingga "sangat setuju" (Tabel 2.1).

Tabel 2.1 Skala Likert

\begin{tabular}{ll}
\hline & Skala Likert \\
\hline 1 & Sangat tidak setuju \\
2 & Tidak setuju \\
3 & Agak tidak setuju \\
4 & Agak setuju \\
5 & Setuju \\
6 & Sangat setuju \\
\hline
\end{tabular}

\section{Hasil dan Pembahasan}

Profil responden mencakup informasi pribadi seperti status pernikahan, pekerjaan, lokasi kerja pada masa pandemi (di rumah atau di kantor) berpengaruh terhadap food safety dan food service karena potensi makan di luar ketika WFO lebih sering dibanding WFH, frekuensi dine-in di restoran, teman makan di luar, dan alasan tidak makan di rumah (Tabel 3.1). Hal ini dilakukan untuk mengantisipasi pola respon yang berbeda terhadap pernyataan yang diberikan. 
Tabel 3.1. Profil Responden

\begin{tabular}{lc}
\hline \multicolumn{1}{c}{ Deskripsi } & $\%$ \\
\hline Status Pernikahan & \\
Menikah & $34 \%$ \\
Tidak menikah & $66 \%$ \\
Pekerjaan & \\
Guru & $3 \%$ \\
Pelajar & $6 \%$ \\
Ibu Rumah Tangga & $6 \%$ \\
Dokter & $5 \%$ \\
Wirausaha & $20 \%$ \\
Karyawan Swasta & $25 \%$ \\
Mahasiswa & $35 \%$ \\
Lokasi kerja selama pandemi & \\
WFH (work from home) & $59 \%$ \\
WFO (work from office) & $41 \%$ \\
\hline
\end{tabular}

Ketika dilakukan uji pada measurements dengan sample control sejumlah 30 responden, sejumlah 13 pernyataan harus dibuang karena tidak dapat mencapai loading 0,6. Dengan demikian pengujian pada sampel penelitian hanya dilakukan dengan menggunakan delapan belas pernyataan.

Uji asumsi normalitas dilakukan dengan melihat pada skewness dan kurtosis (Hair Jr. et al., 2014) dengan nilai maksimal ditetapkan +/- 3. (Hair Jr. et al., 2014) Hasil uji normalitas dapat dilihat pada Tabel 3.2 yang menunjukkan bahwa nilai skweness dan kurtosis berada di bawah nilai +/- 3 .

Tabel 3.2 Measurements, Loadings, Standard Deviasi, Skewness, dan Kurtosis

\begin{tabular}{|c|c|c|c|c|c|}
\hline \multicolumn{2}{|r|}{ Measurements } & Loadings & $\begin{array}{l}\text { Standar } \\
\text { Deviasi }\end{array}$ & Skewness & Kurtosis \\
\hline \multicolumn{6}{|c|}{ X1. Food Safety } \\
\hline $\mathrm{X} 1.1$ & $\begin{array}{l}\text { Selama masa pandemic, Anda } \\
\text { memperhatikan kebersihan dengan } \\
\text { mencuci tangan selama minimal } 20 \\
\text { detik sebelum dan sesudah makan di } \\
\text { restoran. }\end{array}$ & 0,843 & 1,023 & 1,514 & $-1,405$ \\
\hline $\mathrm{X} 1.2$ & $\begin{array}{l}\text { Anda membersihkan meja dan kursi } \\
\text { sebelum dine-in di restoran. }\end{array}$ & 0,692 & 1,394 & $-0,090$ & $-1,024$ \\
\hline $\mathrm{X} 1.3$ & $\begin{array}{l}\text { Saat dine-in, Anda selalu } \\
\text { membersihkan peralatan makan seperti } \\
\text { sendok dan garpu sebelum makan di } \\
\text { restoran. }\end{array}$ & 0,633 & 0,966 & 2,290 & $-1,735$ \\
\hline $\mathrm{X} 1.4$ & $\begin{array}{l}\text { Saat dine-in, Anda memperhatikan para } \\
\text { pelayan menggunakan masker/face }\end{array}$ & 0,679 & 0,527 & 1,301 & $-1,469$ \\
\hline
\end{tabular}




\begin{tabular}{|c|c|c|c|c|c|}
\hline \multicolumn{2}{|r|}{ Measurements } & Loadings & \multirow[t]{2}{*}{$\begin{array}{l}\text { Standar } \\
\text { Deviasi }\end{array}$} & \multirow[t]{2}{*}{ Skewness } & \multirow[t]{2}{*}{ Kurtosis } \\
\hline & shield setiap saat. & & & & \\
\hline $\mathrm{X} 1.5$ & $\begin{array}{l}\text { Saat dine-in, Anda memperhatikan para } \\
\text { pelayan menggunakan sarung tangan } \\
\text { setiap saat. }\end{array}$ & 0,746 & 1,146 & $-0,202$ & $-0,894$ \\
\hline X1.6 & $\begin{array}{l}\text { Saat dine-in, Anda memperhatikan para } \\
\text { pelayan menggunakan penutup kepala / } \\
\text { hair net setiap saat. }\end{array}$ & 0,753 & 1,369 & $-0,645$ & $-0,550$ \\
\hline \multicolumn{6}{|c|}{ X2. Food Service } \\
\hline $\mathrm{X} 2.1$ & $\begin{array}{l}\text { Saat dine-in, restoran menggunakan / } \\
\text { menyediakan akrilik sebagai penyekat } \\
\text { di meja. }\end{array}$ & 0,836 & 1,165 & 1,490 & $-1,247$ \\
\hline $\mathrm{X} 2.2$ & $\begin{array}{l}\text { Saat dine-in, restoran menggunakan / } \\
\text { menyediakan tanda "X" sebagai simbol } \\
\text { menjaga jarak dengan orang. }\end{array}$ & 0,869 & 1.236 & $-0,144$ & $-1,037$ \\
\hline $\mathrm{X} 2.3$ & $\begin{array}{l}\text { Suhu tubuh Anda di ukur sebelum } \\
\text { memasuki restoran. }\end{array}$ & 0,910 & 1,364 & 0,146 & $-1,056$ \\
\hline $\mathrm{X} 2.4$ & $\begin{array}{l}\text { Terdapat papan tulisan suhu tubuh } \\
\text { setiap pelayan saat Anda dine-in di } \\
\text { restoran? }\end{array}$ & 0,927 & 1.269 & 0,410 & $-1,029$ \\
\hline $\mathrm{X} 2.5$ & $\begin{array}{l}\text { Dalam pelayanan makanan di restoran, } \\
\text { pelayan mengantarkan makanan } \\
\text { menggunakan sarung tangan. }\end{array}$ & 0,864 & 1,114 & 0,313 & $-1,092$ \\
\hline $\mathrm{X} 2.6$ & $\begin{array}{l}\text { Saat Anda dine-in, peralatan yang } \\
\text { berhubungan dengan makanan (nampan } \\
\text { / baki) dibersihkan terlebih dahulu oleh } \\
\text { pelayan setelah menyajikan makanan } \\
\text { ke orang lain. }\end{array}$ & 0,709 & 0,808 & $-0,413$ & $-0,823$ \\
\hline $\mathrm{X} 2.7$ & $\begin{array}{l}\text { Saat Anda dine-in di restoran, pelayan } \\
\text { menjaga kebersihan meja kasir. }\end{array}$ & 0,847 & 1,649 & $-0,997$ & $-0,625$ \\
\hline $\mathrm{X} 2.8$ & $\begin{array}{l}\text { Saat Anda dine-in di restoran, pelayan } \\
\text { menjaga kebersihan toilet. }\end{array}$ & 0,816 & 1,714 & $-0,683$ & $-0,831$ \\
\hline \multicolumn{6}{|c|}{ Y. Eating Habit } \\
\hline Y1.1 & $\begin{array}{l}\text { Selama masa pandemic, porsi makan } \\
\text { anda sama saja. }\end{array}$ & 0,631 & 1,840 & $-1,192$ & $-0,488$ \\
\hline Y1.2 & $\begin{array}{l}\text { Saat dine-in, penyajian (penampilan } \\
\text { makanan) di restoran membuat Anda } \\
\text { berselera untuk makan. }\end{array}$ & 0,868 & 1,210 & 2.331 & $-1,671$ \\
\hline Y1.3 & $\begin{array}{l}\text { Saat dine-in, suasana di restoran } \\
\text { membuat Anda berselera untuk makan. }\end{array}$ & 8,816 & 0,964 & 1,092 & $-1,244$ \\
\hline Y1.4 & $\begin{array}{l}\text { Saat dine-in, preferensi restoran saat } \\
\text { Anda memesan makanan baru dimasak }\end{array}$ & 0,745 & 1,038 & 2,426 & $-1,758$ \\
\hline
\end{tabular}




Measurements Loadings $\begin{array}{ll}\text { Standar } \\ \text { Deviasi }\end{array}$ Skewness Kurtosis

menjadi pilihan utama dibandingkan

restoran siap saji (Masakan

Padang/Buffet).

Tabel 3.3 menunjukkan hasil uji reliabilitas dengan Chronbach's Alpha. Seluruh nilai Chronbach's Alpha menunjukkan angka lebih besar daripada 0,7. Composite reliability juga dapat dilihat pada Tabel 3.3, dengan keseluruhan nilai lebih besar daripada 0,7. Dengan demikian memenuhi syarat nilai minimum composite reliability. Disimpulkan, seluruh measurements dapat dikatakan reliabel. Adapun uji validititas dengan menggunakan loading factor dapat dilihat pada Tabel 3.2. Data menunjukkan bahwa seluruh nilai loadings lebih besar daripada 0,6. Convergent validity $(A V E)$ dapat dilihat pada Tabel 3.3, yang menunjukkan bahwa keseluruhan nilai convergent validity (AVE) lebih besar daripada 0,5 .

Tabel 3.3 Chronbanch's Alpha, Composite Reliability, dan Convergent Validity (AVE)

\begin{tabular}{lccc}
\hline & Chronbach's Alpha & $\begin{array}{c}\text { Composite } \\
\text { Reliability }\end{array}$ & $\begin{array}{c}\text { Covergent } \\
\text { Validity (AVE) }\end{array}$ \\
\hline Eating Behavior (Y1) & 0,764 & 0,852 & 0,593 \\
Food Safety (X1) & 0,820 & 0,870 & 0,529 \\
Food Service (X2) & 0,946 & 0,955 & 0,728 \\
\hline
\end{tabular}

Discriminant validity dengan menggunakan metode Fornell-Larcker dapat dilihat pada Tabel 3.4. Data menujukkan bahwa keseluruhan nilai akar AVE lebih besar daripada nilai korelasi antar variabel. Dengan demikian seluruh measurements dapat dikatakan valid.

Tabel 3.4 Discriminant Validity

\begin{tabular}{lccc}
\hline & Eating Behavior (Y1) & Food Safety (X1) & Food Service (X2) \\
\hline Eating Behavior (Y1) & $\mathbf{0 , 7 7 0}$ & & \\
Food Safety (X1) & 0,516 & $\mathbf{0 , 7 2 7}$ & \\
Food Service (X2) & 0,430 & 0,703 & $\mathbf{0 , 8 5 3}$ \\
\hline
\end{tabular}

Hasil uji inner model dapat dilihat pada Tabel 3.5. Hubungan antara food safety dan food service memiliki path coefficient dengan nilai 0,703, $\mathrm{T}=10,647, p<0,001$. Dengan demikian Hipothesis 1. diterima. Hubungan antara food service dengan eating habit memiliki path coefficient dengan nilai $0,133, \mathrm{~T}=0,686, p=0,493$. Dengan demikian Hipothesis 2. ditolak. Adapun hubungan antara food safety dengan eating habit menunjukkan path coefficient dengan nilai 0,422, $\mathrm{T}=2,274, p<0,05$. Dengan demikian Hipothesis 3 diterima.

Selanjutnya $\mathrm{R}^{2}$ variabel food service menunjukkan nilai 49 persen. Hal ini berarti variabel food safety menjelaskan variabel food service sebesar 49 persen. Selebihnya sebesar 51 persen dijelaskan oleh variabel lain yang tidak diuji dalam penelitian ini. 
Selanjutnya, nilai $\mathrm{R}^{2}$ variabel eating habit adalah sebesar 28 persen. Dengan demikian variabel food service dan food safety menjelaskan variabel eating habit sebesar 28 persen. Selebihnya yaitu sebesar 72 persen dijelaskan oleh variabel lain yang tidak diuji dalam penelitian ini.

Tabel 3.5 Path Coefficient, T, $p$

\begin{tabular}{lcccc}
\hline & $\begin{array}{c}\text { Path } \\
\text { Coefficient }\end{array}$ & $\mathrm{T}$ & $p$ & Keterangan(*) \\
\hline H1. Food Safety $\rightarrow$ Food Service & 0,703 & 10,647 & 0,000 & Signifikan \\
H2. Food Service $\rightarrow$ Eating Habit & 0,133 & 0,686 & 0,493 & Tidak Signifikan \\
H3. Food Safety $\rightarrow$ Eating Habit & 0,422 & 2,274 & 0,023 & Signifikan \\
\hline
\end{tabular}

Keterangan : $\mathrm{N}=64$ - Bootstrap 500. Signifikansi 5\%. T 2-tailed.

Selanjutnya hasil olahan data menunjukkan koefisien specific indirect effect food safety $\rightarrow$ food service $\rightarrow$ eating habit sebesar 0,094 dengan $p=0,505$. Hal ini menunjukkan bahwa food service tidak memediasi hubungan pengaruh antara food safety dan eating habit.

\section{Kesimpulan}

Studi ini bertujuan untuk meneliti pengaruh food safety dan food service terhadap eating habit selama masa pandemi COVID-19. Berdasarkan data yang telah diolah dan diuji dengan PLS-SEM (Hair et al. 2014), terlihat bahwa food service tidak berbengaruh terhadap eating habit. Ada beberapa faktor yang memungkinan food service tidak berpengaruh terhadap eating habit. Perilaku setiap orang dalam menanggapi pelayanan makanan berbeda-beda. Oleh karena itu ketika mereka dine-in sebagian akan menjaga kebersihan. Eating habits para responden juga tidak mengalami perubahan baik bertambah atau berkurang selama masa pademi (Poelman et al. 2020). CNN Indonesia menyatakan bahwa pelayanan restoran mengikuti protokol kesehatan Pemerintah dan melaksanakan PSBB dalam pemberlakukan jam operasional. Maka dari itu dapat dikatakan bahwa eating habit tidak dipengaruhi oleh food service karena setiap pelanggan yang datang sudah mempersiapkan diri untuk menjaga kesehatan (Fanelli, 2021) Ketika konsumen mempersepsi food products tetap aman dan tidak akan tekonaminasi oleh virus dan bakteri karena tindakan mandiri mereka, (Olaimat et al. 2020) mereka tidak merubah eating habits.

Di sisi lain food safety berpengaruh signifikan terhadap eating habit. Hal ini dikarenakan keamanan pangan merupakan aspek utama yang diberikan dan diperhatikan oleh pemilik restoran dalam melayani para pelanggan sehingga mereka dapat merasa aman ketika dine-in. Setiap keamanan pangan dijaga baik dari pengolahan bahan produk mentah hingga penyajian produk makanan (Han et al. 2020) Para pelanggan akan merasa aman ketika kebersihan lingkungan di sekitar restoran terjaga (de Andrade et al. 2020). Secara tidak langsung lingkungan sekitar akan berpengaruh terhadap bahan produk, food operations, dan mengkontaminasi makanan yang akan disajikan kepada pelanggan. Maka dari itu food safety sangatlah penting dan merupakan pondasi bagi food service (Shahbaz et al. 2020). Adapun penerapan precautionary measure juga diterapkan dalam pelayanan makanan untuk menjaga keamanan dan kesehatan setiap pelanggan (Shahbaz et al. 2020). 
Batasan dalam penelitian ini adalah jumlah sampel yang tidak besar, sehingga penelitian ini masih dapat dikembangkan lebih lanjut. Adapun, saran bari para pemangku kepentingan adalah agar restoran dan rumah makan tetap wajib melakukan semua persiapan dan menyediakan fasilitas protokol kesehatan sesuai peraturan pemerintah. Lebih jauh, restoran juga dapat menyediakan sejumlah bahan pembersih lain yang dapat digunakan secara mandiri oleh konsumen selain hand satitizer dan pencuci tangan. Termasuk di dalam bahan ini adalah semprotan pembersih meja, kursi, dan juga pembersih alat makan sekali pakai.

\section{Ucapan Terima Kasih}

Dengan demikian penelitian ini telah dilaksanakan dan dibuat dengan sebenar-benarnya. Penulis berterima kasih kepada pihak-pihak yang telah berkontribusi dalam pembimbingan research paper ini. Penulis juga berterima kasih kepada Program Studi Pariwisata, Fakultas Pariwisata, Universitas Ciputra Surabaya yang telah memberikan kesempatan kepada penulis untuk mengikuti lomba ini. Penulis berterima kasih kepada Bapak Lexi Pranata Budhidarmanto, S.Kom., M.B.A., M.M., C.E.M., CIQaR. dan Bapak I Dewa Gde Satrya Widya Dutha, S.E., M.M. yang telah membimbing dalam pelaksanaan lomba, serta Ibu Dra. Ida Ayu Indira Swari, M.M. yang telah membimbimbing mengintreprestasikan data dalam penelitian ini. Tidak lupa penulis juga berterima kasih kepada komunitas kulineran di Surabaya yang telah menjadi sampel dalam penelitian ini. Mohon maaf apabila ada salah kata dan penulisan dalam penelitian ini karena adanya keterbatasan yang ada penulis ucapkan terima kasih atas kerja sama rekan-rekan sekalian.

\section{Pustaka}

de Andrade, Marcel Levy, Elke Stedefeldt, Lais Mariano Zanin, and Diogo Thimoteo da Cunha. 2020. "Food Safety Culture in Food Services with Different Degrees of Risk for Foodborne Diseases in Brazil." Food Control 112(November 2019): 107152. https://doi.org/10.1016/j.foodcont.2020.107152.

Chow, Lim Soon. 2020. "Foodservice Waging War Against Covid-19 Crisis." Journal of Tourism, Hospitality and Environment Management (JTHEM) 5(19): 41-49.

Edwards, John S.A. 2013. "The Foodservice Industry: Eating out Is More than Just a Meal." Food Quality and Preference 27(2): 223-29. http://dx.doi.org/10.1016/j.foodqual.2012.02.003.

Fanelli, Rosa Maria. 2021. "Changes in the Food-Related Behaviour of Italian Consumers during the COVID-19 Pandemic."

Hair, Joe F., Marko Sarstedt, Lucas Hopkins, and Volker G. Kuppelwieser. 2014. "Partial Least Squares Structural Equation Modeling (PLS-SEM): An Emerging Tool in Business Research.” European Business Review 26(2): 106-21.

Han, Jie, Xue Zhang, Shanshan He, and Puqi Jia. 2020. "Can the Coronavirus Disease Be Transmitted from Food? A Review of Evidence, Risks, Policies and Knowledge Gaps National Health Commission of China." Environmental Chemistry Letters (0123456789). https://doi.org/10.1007/s10311-020-01101-x.

Lee, Kyung Eun. 2019. “Students' Dietary Habits, Food Service Satisfaction, and Attitude 
toward School Meals Enhance Meal Consumption in School Food Service." Nutrition Research and Practice 13(6): 555-63.

Olaimat, Amin N. et al. 2020. "Food Safety During and After the Era of COVID-19 Pandemic." Frontiers in Microbiology 11(August).

Poelman, Maartje P, Marleen Gillebaart, Caroline Schlinkert, and S Coosje Dijkstra. 2020. "Since January 2020 Elsevier Has Created a COVID-19 Resource Centre with Free Information in English and Mandarin on the Novel Coronavirus COVID- 19 . The COVID-19 Resource Centre Is Hosted on Elsevier Connect, the Company' s Public News and Information." (January).

Di Renzo, Laura et al. 2020. "Eating Habits and Lifestyle Changes during COVID-19 Lockdown: An Italian Survey." Journal of Translational Medicine 18(1): 1-15. https://doi.org/10.1186/s12967-020-02399-5.

Shahbaz, Muhammad et al. 2020. "Food Safety and COVID-19: Precautionary Measures to Limit the Spread of Coronavirus at Food Service and Retail Sector." Journal of Pure and Applied Microbiology 14(1): 749-56.

Chin, W.W. (1998). The partial least squares approach to structural equation modeling. G.A. Marcoulides (Ed.), (2014). Modern Methods for Business Research (pp.295336). London, England: Lawrence Erlbaum.

Ghozali, Imam and Hengky Latan. 2015. Partial Least Squares: Concepts, Technique, and Application use SmartPLS 3.0 Program. Edition 2. Semarang: Undip.

CNN Indonesia. 2020. Percobaan : Melihat Penerapan Aturan Kesehatan di Restoran, website : https://www.cnnindonesia.com/gaya-hidup/20200716194650-262525641/percobaan-melihat-penerapan-aturan-kesehatan-di-restoran, Diakses pada tanggal : 19 Desember 2020.

CNN Indonesia. 2020. Protokol Kesehatan di Restoran dan Kafe untuk Cegah Covid-19, website : https://www.cnnindonesia.com/gaya-hidup/20200715112832-255524881/protokol-kesehatan-di-restoran-dan-kafe-untuk-cegah-covid-19, Diakses pada tanggal : 21 Desember 2020.

Kompas. 2020. Diumumkan Awal Maret, Ahli : Corona Masuk Indonesia dari Januari, website : https://www.kompas.com/sains/read/2020/05/11/130600623/diumumkanawal-maret-ahli--virus-corona-masuk-indonesia-dari-januari, Diakses pada tanggal : 19 Desember 2020.

World Health Organization (WHO). 2020. \#HealthyAtHome : Healthy Diet, website : https://www.who.int/campaigns/connecting-the-world-to-combatcoronavirus/healthyathome/healthyathome---healthydiet\#: :text=There\%20is\%20no\%20evidence\%20that,food\%2Dborne\%20illnesses, Diakses pada tanggal : 19 Desember 2020. 